\title{
Bust size and pain of the musculoskeletal system - a literature review
}

\author{
Grzegorz Zieliński' ${ }^{1}$ Zuzanna Filipiak², Marta Suwała', Michał Ginszt' ${ }^{1}$, Piotr Majcher ${ }^{1}$ \\ ${ }^{1}$ Medical University, Lublin, Poland \\ ${ }^{2}$ Medical University, Warsaw, Poland
}

Zieliński G, Filipiak Z, Suwała M, Ginszt M, Majcher P. Bust size and pain of the musculoskeletal system - a literature review. Med Og Nauk Zdr. 2019; 25(1): 44-47. doi: 10.26444/monz/104635

\begin{abstract}
Objectives. It is generally accepted that large breast sizes among women contribute to the development of back pain and poor posture. The aim of our research was to determine if the hypothesis that the size of the breasts has an impact on the pain of the musculoskeletal system in women, can be confirmed or denied on the basis of available literature.

Material and methods. A systematic review based on the contents of the PubMed database, ResearchGate, ScienceDirect, and Google Scholar databases was performed. In order to identify relevant publications, a search using a combination of key words "breast size", "spine pain" and "musculoskeletal pain"(according to Medical Subject Headings - MeSH) was performed. Four studies have been included in our review.

Results. The correlation between breast size and pain is confirmed by three studies. One study stands in opposition to the others. Considering the value of evidence and results in peer-reviewed publications, we conclude that there is considerable evidence to support the hypothesis that the size of the breasts affects the painfulness of the musculoskeletal system.

Conclusions. Due to the small amount of available literature, we find that studies on the impact of bust size on pain of the musculoskeletal system should be continued on a larger scale. Based on the above review, we conclude that there is considerable evidence to support the hypothesis that the size of the breasts affects the painfulness of the musculoskeletal system.
\end{abstract}

\section{Key words}

breast size, pain

\section{INTRODUCTION}

Compared with men, women have a healthier lifestyle, are less likely to be overweight, have less stressful jobs or do not work outside the home. However, women more frequently suffer from back pain [1]. Chronic pain also occurs more often in women than in men and increases with age [2].

It is generally accepted that large breast sizes in women contribute to the development of back pain and poor posture. The effects of having a large breast on vertebral movements and muscle activation traits are still poorly understood [3]. Women with large breasts usually have a number of complaints relating to the skeletal system, and complaints such as neck strain, headache, aching shoulders, heavy anterior chest, and paresthesiae of the little fingers disappear after reduction mammoplasty $[4,5]$. Some people combine the above ailment with increased thoracic kyphosis in women with large breasts, which causes poor mobility of the upper thoracic spine. This ailment has also been identified as a prognostic factor of neck and shoulder pain [6,7]. Some authors see the causes of discomfort in the torso muscles disbalance and significant forces acting on the erector spinae muscle by large breasts, which may lead to hyperkyphosis and pain [8]. The interaction of increased flexion torque on the thoracic spine and weaker muscles in the posterior part of the thoracic spine may lead to postural changes and increased tissue loading in the thoracic region of the vertebral column, and secondary to the occurrence of musculoskeletal pain

Address for correspondence: Marta Suwała, Medical University, Aleje Racławickie 1, 20-059, Lublin, Poland

E-mail: martarucinska@interia.pl

Received: 11 December 2018; Accepted: 22 February 2019 among women with large breasts [9]. An important issue is also that the prevalence of this unique women's health problem is likely to escalate because the average size of the bra cup has increased over the last two decades from a small one bra cup size to a large bra cup size [9]

\section{OBJECTIVE}

The aim of the research was to determine whether the hypothesis that the size of the breasts has an impact on the pain of the musculoskeletal system in women, can be confirmed or denied on the basis of available literature.

\section{MATERIALS AND METHOD}

Material for the study consisted of publications identified by searches using the PubMed database, ResearchGate, ScienceDirect, and Google Scholar. In order to identify relevant publications, a search using a combination of key words "breast size", "spine pain" and "musculoskeletal pain" (according to Medical Subject Headings - MeSH) was performed.

After evaluation, four studies were included in the review. How they were focused on different aspects of this issue will be discussed in detail. Aims, methods and material of the studies, as well as results and conclusions, are described in the data extraction table (Tab. 1).

Studies were scored according to questions shown in Table 2. The questions for scoring are based on the "Cochrane Handbook for Systematic Reviews of Interventions 4.2.6 
Table 1. Data extraction

\begin{tabular}{|c|c|c|c|}
\hline $\begin{array}{l}\text { Author, } \\
\text { title, } \\
\text { year. }\end{array}$ & $\begin{array}{l}\text { Materials and } \\
\text { methods. }\end{array}$ & Results & Conclusions \\
\hline $\begin{array}{l}\text { K. Wood et al. } \\
\text { Breast size, bra fit and } \\
\text { thoracic pain in young } \\
\text { women: a } \\
\text { correlational study. } \\
2008\end{array}$ & $\begin{array}{l}\text { Materials: } 30 \text { nulliparous } \\
\text { women (18-26 years), with } \\
\text { thoracic spine or posterior chest } \\
\text { wall pain, who wore bras during } \\
\text { daytime. } \\
\text { Methods: Pain (Short Form } \\
\text { McGill Pain Questionnaire), bra } \\
\text { size (Triumph International), bra } \\
\text { fit (Triumph International). }\end{array}$ & $\begin{array}{l}\text { Most }(80 \%) \text { women wore incorrectly sized bras: } 70 \% \\
\text { wore bras that were too small, } 10 \% \text { wore bras that } \\
\text { were too large. Breast size was negatively correlated } \\
\text { with both bra size }(r=-0.78) \text { and bra fit }(r=-0.50) \text {. } \\
\text { Negligible relationships were found between pain } \\
\text { and bra fit, and breast size and pain. Menstrual cycle } \\
\text { stage was moderately positively correlated with bra } \\
\text { fit }(r=0.32) \text {. }\end{array}$ & $\begin{array}{l}\text { In young, nulliparous women, thoracic pain } \\
\text { appears unrelated to breast size. Bra fit is } \\
\text { moderately related to stage of menstrual } \\
\text { cycle suggesting that this research may be } \\
\text { somewhat confounded by hormonal changes } \\
\text { or reproductive stage. Further research is } \\
\text { needed to clarify whether there is a relationship } \\
\text { between breast size or bra fit and thoracic pain } \\
\text { in women during times of hormonal change. }\end{array}$ \\
\hline $\begin{array}{l}\text { M. Oo et al. } \\
\text { Relationship Between } \\
\text { Brassiere Cup Size and } \\
\text { Shoulder-Neck Pain in } \\
\text { Women } \\
2012\end{array}$ & $\begin{array}{l}\text { Materials: } 339 \text { women, the age } \\
\text { range of the participants was } 18 \\
\text { to } 77 \text { years (average } 44.5 \text { years). } \\
\text { Methods: original protocol } \\
\text { as approved by the ethics } \\
\text { committee }\end{array}$ & $\begin{array}{l}\text { No significant relationship between shoulder-neck } \\
\text { pain and brassiere cup size were showed. However, } \\
\text { after participants were classified into two groups } \\
\text { (small brassiere cup size and large brassiere cup size } \\
\text { with } 219 \text { and } 120 \text { participants, respectively), there was } \\
\text { a significant positive correlation between shoulder- } \\
\text { neck pain and large brassiere cup size ( } p<0.05 \text { ). There } \\
\text { was no significant relationship between shoulder- } \\
\text { neck pain and breast size. }\end{array}$ & $\begin{array}{l}\text { Large brassiere cup size is an important cause of } \\
\text { shoulder-neck pain. }\end{array}$ \\
\hline $\begin{array}{l}\text { L. Spencer et al. } \\
\text { Breast size, thoracic } \\
\text { kyphosis \& thoracic spine } \\
\text { pain - association \& } \\
\text { relevance of bra fitting } \\
\text { in post-menopausal } \\
\text { women: a correlational } \\
\text { study } \\
2013\end{array}$ & $\begin{array}{l}\text { Materials: } 51 \text { post-menopausal } \\
\text { women ( } 50-84 \text { years) with and } \\
\text { without thoracic pain, who wore } \\
\text { a bra on a daily basis. } \\
\text { Methods: original protocol, } \\
\text { anthropometrical measurement } \\
\text { (breast size \& thoracic } \\
\text { kyphosis) and thoracic pain } \\
\text { measurements. }\end{array}$ & $\begin{array}{l}\text { Pain was significantly related to breast size, body } \\
\text { weight and BMI at mid thoracic levels (T7-8). In } \\
\text { contrast self-reported } \\
\text { thoracic pain was not correlated with age or index } \\
\text { of kyphosis (thoracic kyphosis). Women with } \\
\text { thoracic pain were no more likely to have their bra } \\
\text { professionally fitted whereas women with a higher } \\
\text { BMI and larger breasts were more likely to have their } \\
\text { bra professionally fitted. }\end{array}$ & $\begin{array}{l}\text { Larger breasts and increased BMI are associated } \\
\text { with thoracic pain in postmenopausal women. } \\
\text { This is unrelated to thoracic kyphosis. Increasing } \\
\text { breast size and how a bra is worn may have } \\
\text { biomechanical implications for the loaded } \\
\text { thoracic spine and surrounding musculature. } \\
\text { Post-menopause women } \\
\text { present with a spectrum of anthropometrical } \\
\text { changes that have the potential to contribute to } \\
\text { altered biomechanics and affect pain states in } \\
\text { the thoracic spine. }\end{array}$ \\
\hline $\begin{array}{l}\text { DE. McGhee et al. } \\
\text { Upper torso pain } \\
\text { and musculoskeletal } \\
\text { structure and function in } \\
\text { women with and without } \\
\text { large breasts: A cross } \\
\text { sectional study. } \\
2018\end{array}$ & $\begin{array}{l}\text { Materials: } 53 \text { women (18-60 } \\
\text { years, mean } 44.8 \text { year) } \\
\text { Methods: a linear regression, } \\
\text { adjusting for body mass, } \\
\text { compared the upper torso pain, } \\
\text { thoracic flexion torque due to } \\
\text { breast mass, thoracic kyphosis, } \\
\text { shoulder active range-of-motion, } \\
\text { and scapular retraction muscle }\end{array}$ & $\begin{array}{l}\text { Women with large breasts reported a higher upper } \\
\text { torso pain score }(46.6,95 \% \mathrm{Cl} 33.3-58.0 \text { versus } 24.1 \text {, } \\
95 \% \mathrm{Cl} 12.5-37.8) \text {, accompanied by a larger flexion } \\
\text { torque }(5.9 \mathrm{Nm}, 95 \% \mathrm{Cl} 4.5-5.8 \mathrm{Nm} \text { versus } 0.9 \mathrm{Nm}, 95 \% \mathrm{Cl} \\
0.8-2.4 \mathrm{Nm}) \text {, greater thoracic kyphosis }\left(34^{\circ}, 95 \% \mathrm{Cl}\right. \\
\left.31-38^{\circ} \text { versus } 27^{\circ}, 95 \% \mathrm{Cl} 24-31^{\circ}\right) \text {, decreased shoulder } \\
\text { elevation range-of-motion }\left(160^{\circ}, 95 \% \mathrm{Cl} 158-163^{\circ}\right. \\
\left.\text { versus } 169^{\circ}, 95 \% \mathrm{Cl} 166-172^{\circ}\right) \text {, and decreased scapular } \\
\text { retraction endurance-strength }(511.4 \mathrm{~s}, 95 \% \mathrm{Cl} 362.2- \\
691.3 \mathrm{~s} \text { versus } 875.8 \mathrm{~s}, 95 \% \mathrm{Cl} 691.5-1028.4 \mathrm{~s}) \text { compared } \\
\text { to the women with small breasts. }\end{array}$ & $\begin{array}{l}\text { Differences in the upper torso posture, range- } \\
\text { of-motion, and muscle strength of women with } \\
\text { large breasts provides insight into underlying } \\
\text { causes of their musculoskeletal pain. This } \\
\text { information can be used to develop evidence- } \\
\text { based assessment and treatment strategies to } \\
\text { relieve and prevent symptom progression. }\end{array}$ \\
\hline
\end{tabular}

Updated September 2006", PRISMA 2009 Checklist, “Advice on how to write a systematic review, JM Wardlaw, 14 January 2010", and the quality assessment tool for diagnostic accuracy studies (QUADAS) recommended by the Cochrane Collaboration. Each article was scored from $0-2$ and the scores were tallied-up. The methodology of each selected article was evaluated and information placed in Table 3.

\section{RESULTS}

In this review, different methods of assessing pain and methods of statistical analysis were applied, which undoubtedly influenced the obtained results (Tab. 1). Wood et al. obtained high values of evidence (12 points), the remaining studies were in the criterion of moderate value of evidence (Tab. 2,3). Considering the small amount of available literature, the value of evidence, various groups of subjects with average numbers, inconsistency of results in peer-reviewed publications, it was found that there is considerable evidence to support the hypothesis that the size of the breasts affects the painfulness of the musculoskeletal system.
Table 2. Scoring questions and scores

\begin{tabular}{lll}
\hline \multicolumn{2}{l}{ Scoring questions and stores } \\
\hline Q1 Sample size & $\begin{array}{l}0-9-0 \mathrm{pkt} \\
10-99-1 \mathrm{pkt} \\
>100-2 \mathrm{pkt}\end{array}$ \\
\hline Q2 Control group & $\begin{array}{l}\text { none }-0 \mathrm{pts} \\
\text { present }-2 \mathrm{pts}\end{array}$ \\
\hline Q3 Inclusion criteria & $\begin{array}{l}\text { none }-0 \mathrm{pts} \\
\text { present }-2 \mathrm{pts}\end{array}$ \\
\hline Q4 Exclusion criteria & $\begin{array}{l}\text { none }-0 \text { pts } \\
\text { surgery, concomitant pain disorders OR other } \\
\text { medications use }-1 \text { pt } \\
\text { surgery, concomitant pain disorders AND other } \\
\text { medications use }-2 \text { pts }\end{array}$ \\
\hline Q5 $\begin{array}{l}\text { Use of standardized } \\
\text { protocol }\end{array}$ & $\begin{array}{l}\text { none }-0 \text { pts } \\
\text { VAS score }-1 \text { pts } \\
\text { questionnaires pain }-2 \text { pts }\end{array}$ \\
\hline Q6 Assessment of the & $\begin{array}{l}\text { none }-0 \text { pts } \\
\text { anthropometric }-2 \text { pts }\end{array}$ \\
\hline breast size & $\begin{array}{l}\text { present }-0 \text { pts } \\
\text { no data }-1 \mathrm{pt} \\
\text { none }-2 \text { pts }\end{array}$ \\
\hline
\end{tabular}

Scores:

$0-8$ were rated as the poor value of evidence,

9-11 were rated as a moderate, value of evidence,

12-14 were rated high value of evidence. 
Table 3. Scoring

\begin{tabular}{|c|c|c|c|c|c|c|c|c|c|}
\hline \multirow{2}{*}{ Authors } & \multirow{2}{*}{ Title } & \multicolumn{7}{|c|}{ Scoring } & \multirow{2}{*}{$\begin{array}{l}\text { To- } \\
\text { tal }\end{array}$} \\
\hline & & Q1 & Q2 & Q3 & Q4 & Q5 & Q6 & Q7 & \\
\hline $\begin{array}{l}\text { K. Wood } \\
\text { et al. }\end{array}$ & $\begin{array}{l}\text { Breast size, bra fit and thoracic } \\
\text { pain in young women: } \\
\text { a correlational study. }\end{array}$ & 1 & 2 & 2 & 1 & 2 & 2 & 2 & 12 \\
\hline $\begin{array}{l}\text { M. Oo } \\
\text { et al. }\end{array}$ & $\begin{array}{l}\text { Relationship Between Brassiere } \\
\text { Cup Size and Shoulder-Neck } \\
\text { Pain in Women }\end{array}$ & 2 & 2 & 0 & 1 & 1 & 1 & 2 & 9 \\
\hline $\begin{array}{l}\text { L. } \\
\text { Spencer } \\
\text { et al. }\end{array}$ & $\begin{array}{l}\text { Breast size, thoracic kyphosis } \\
\text { \& thoracic spine pain - } \\
\text { association \& relevance of bra } \\
\text { fitting in post-menopausal } \\
\text { women: a correlational study }\end{array}$ & 1 & 2 & 0 & 2 & 2 & 2 & 1 & 10 \\
\hline $\begin{array}{l}\text { DE. } \\
\text { McGhee } \\
\text { et al. }\end{array}$ & $\begin{array}{l}\text { Upper torso pain and } \\
\text { musculoskeletal structure and } \\
\text { function in women with and } \\
\text { without large breasts: A cross } \\
\text { sectional study. }\end{array}$ & 1 & 2 & 2 & 1 & 1 & 2 & 2 & 11 \\
\hline
\end{tabular}

\section{DISCUSSION}

In the reviewed studies, three studies [9-11] proved that the size of the breasts is associated with pain of the musculoskeletal system. The above results were explained by Schinkel-Ivy et al. according to whom the torso muscles showed positive, moderately strong correlations with the size of the breast while standing and some movements of the trunk [3]. The size of the breast is associated with a changed posture, which in the long-term perspective, may cause pathological changes leading to pain. Changes in the posture of women with large sized breasts were noted by Barbosa et al., who examined women with breast hypertrophy compared to healthy women. According to their results, women with hypertrophy pedestrians had a changed posture [12]. Studies by Findikcioglu et al. specify that there were significant statistical differences between the groups of women with bra cups A and D in terms of thoracic kyphosis and lordosis angles, and between groups of women with bra cups B and $\mathrm{D}$ in terms of the angle of lumbar lordosis. There was no statistically significant difference between the groups in terms of vertebral lean angle [13]. A change in body posture combined with non-ergonomic work affects the emergence of pain, as evidenced by Nowotny et al. [14]. The results of these studies also seem to be confirmed in three studies proving that the size of the breasts is associated with pain of the musculoskeletal system [9-11].

Chao et al. studied the usefulness of removing breast tissue in symptomatic patients (regardless of amount of tissue removed) to improve their physical disabilities related to breast hypertrophy, and in turn, improve their quality of life. According to them, after the surgery, the body posture improved, perceptible pain was also reduced [15]. Research by Karaslan et al. stated that although breast size may be an important factor affecting posture, the reduction of mammaplastic surgery has little or no radiological impact on the spine [16].

One study in this review did not show a connection between breast size and pain in the musculoskeletal system [17]. This may be due to the age of the respondents (18-26 years) and the final development of the movement apparatus, as well as a small test group. Wood et al. focused mainly on pain complaints within the chest section [17]. The radiological image of the spine in women with large breasts (size of the bra $\mathrm{D}+$ ) showed a much higher thoracic kyphosis, compared with women with small breasts [13].

Extended thoracic kyphosis was associated with anterior head and shoulders posture and altered scapula alignment, which was combined with a reduced range of shoulder movements [6]. In contrast, poor mobility of the upper thoracic spine was also identified as a predictor of neck and shoulder pain [7]. Wood et al. in their study [17] correctly state that the size of the breast does not affect the pain of the thoracic segment, but the researchers did not investigate the impact of the breasts on other parts of the human body.

The assessed works had many limitations, especially the small sample size and no visual imaging evaluation of possible pathological masses that the patients could have had. In addition, the articles differed in the exclusion criteria that could have affect the result. To determine the size of the breasts in Spencer et al. studies. [10], and Wood et al. [17], Triumph's criteria were applied [18] McGhee et al. research was characterized by the most accurate method of determining the size of the breasts from the above review (each breast was scanned while the participants lay prone with their breasts freely suspended between two tables) [10]. Research by Oo et al. [11] did not investigate the size of the breasts, but the size of the bra cup. In this review, different methods of assessing pain and methods of statistical analysis were applied, which undoubtedly influenced the obtained results. Wood et al. had high values of evidence (12 points), the remaining studies were within the criterion for a moderate value of evidence.

\section{CONCLUSIONS}

Considering the small amount of available literature, the value of evidence, various groups of subjects with average numbers, inconsistency of results in peer-reviewed publications, it was found that there is considerable evidence to support the hypothesis that the size of the breasts affects the painfulness of the musculoskeletal system. The results of the reviews were mostly convergent, with only one study obtaining different results from the others. Based on the above review, it can be concluded that there is considerable evidence to support the hypothesis that the size of the bust affects the painfulness of the musculoskeletal system.

\section{REFERENCES}

1. Schneider S, Randoll D, Buchner M. Why do women have back pain more than men? A representative prevalence study in the federal republic of Germany. Clin J Pain 2006; 22(8): 738-47. doi: 10.1097/01. ajp.0000210920.03289.93

2. Kozinoga M, Majchrzycki M, Piotrowska S. Low back pain in women before and after menopause. Prz Menopauzalny 2015; 14(3): 203-7. doi: $10.5114 /$ pm.2015.54347

3. Schinkel-Ivy A, Drake JDM. Breast size impacts spine motion and postural muscle activation. J Back Musculoskelet Rehabil. 2016; 29(4): 741-8. doi: 10.3233/BMR-160680

4. Gonzalez F, Walton RL, Shafer B, et al. Reduction mammaplasty improves symptoms of macromastia. Plast Reconstr Surg. 1993; 91(7): 1270-6.

5. Brühlmann Y, Tschopp H. Breast reduction improves symptoms of macromastia and has a long-lasting effect. Ann Plast Surg. 1998; 41(3): $240-5$. 
6. Lewis JS, Wright C, Green A. Subacromial impingement syndrome: the effect of changing posture on shoulder range of movement. J Orthop Sports Phys Ther. 2005; 35(2): 72-87. doi: 10.2519/jospt.2005.35.2.72

7. Lau KT, Cheung KY, Chan KB, et al. Relationships between sagittal postures of thoracic and cervical spine, presence of neck pain, neck pain severity and disability. Man Ther. 2010; 15(5): 457-62. doi: 10.1016/j. math.2010.03.009

8. Roghani T, Zavieh MK, Manshadi FD, et al. Age-related hyperkyphosis: update of its potential causes and clinical impacts-narrative review. Aging Clin Exp Res. 2017; 29(4): 567-77. doi: 10.1007/s40520-016-0617-3

9. McGhee DE, Coltman KA, Riddiford-Harland DL, et al. Upper torso pain and musculoskeletal structure and function in women with and without large breasts: A cross sectional study. Clin Biomech (Bristol, Avon) 2018; 51: 99-104. doi: 10.1016/j.clinbiomech.2017.12.009

10. Spencer L, Briffa K. Breast size, thoracic kyphosis \& thoracic spine pain - association \& relevance of bra fitting in post-menopausal women: a correlational study. Chiropr Man Therap. 2013; 21: 20. doi: 10.1186/2045-709X-21-20

11. Oo M, Wang Z, Sakakibara T, et al. Relationship Between Brassiere Cup Size and Shoulder-Neck Pain in Women. Open Orthop J. 2012; 6: 140-2. doi: 10.2174/1874325001206010140
12. Barbosa AF, Raggi GC, dos Santos Cardoso Sá C, et al. Postural control in women with breast hypertrophy. Clinics (Sao Paulo) 2012; 67(7): 757-60. doi: 10.6061/clinics/2012(07)09

13. Findikcioglu K, Findikcioglu F, Ozmen S, et al. The impact of breast size on the vertebral column: a radiologic study. Aesthetic Plast Surg 2007; 31(1): 23-7. doi: 10.1007/s00266-006-0178-5

14. Nowotny J, Nowotny-Czupryna O, Brzęk A, et al. Body posture and syndromes of back pain. Ortop Traumatol Rehabil. 2011; 13(1): 59-71.

15. Chao JD, Memmel HC, Redding JF, et al. Reduction mammaplasty is a functional operation, improving quality of life in symptomatic women: a prospective, single-center breast reduction outcome study. Plast Reconstr Surg. 2002; 110(7): 1644-52; discussion 1653-1654. doi: 10.1097/01.PRS.0000033029.01084.57

16. Karaaslan O, Demirkiran HG, Silistreli O, et al. The Effect of Reduction Mammaplasty on the Vertebral Column: A Radiologic Study. ScientificWorldJournal 2013; 2013. doi: 10.1155/2013/701391

17. Wood K, Cameron M, Fitzgerald K. Breast size, bra fit and thoracic pain in young women: a correlational study. Chiropr Osteopat 2008; $16: 1$. doi: $10.1186 / 1746-1340-16-1$

18. Triumph International. Brastylist: Book of Bras. Australia: Triumph International Australia; 2005.

\title{
Wpływ rozmiaru biustu na powstawanie dolegliwości bólowych układu mięśniowo-szkieletowego, przegląd literatury
}

\begin{abstract}
Streszczenie
Cel pracy. Przyjmuje się, że duże rozmiary piersi u kobiet przyczyniają się do rozwoju bólu pleców i złej postawy. Celem naszych badań było ustalenie, czy hipoteza, że wielkość piersi ma wpływ na ból układu mięśniowo-szkieletowego u kobiet, może zostać potwierdzona lub odrzucona na podstawie dostępnej literatury.

Materiał i metody. Dokonano systematycznego przeglądu opartego na zawartości baz danych PubMed, ResearchGate, ScienceDirect i Google Scholar. W celu identyfikacji odpowiednich publikacji przeprowadzono wyszukiwanie za pomocą kombinacji słów kluczowych „rozmiar piersi”, „ból kręgosłupa” i „ból mięśniowo-szkieletowy” (zgodnie z Medical Subject Headings - MeSH). W naszej ocenie uwzględniono cztery badania, które zostały pogrupowane pod kątem różnych aspektów. Wyniki. Korelację między wielkością piersi a bólem potwierdzają trzy badania. Jedno badanie stoi w opozycji do innych. Biorąc pod uwagę wartość dowodów i wyników w recenzowanych publikacjach, dochodzimy do wniosku, że istnieją znaczące dowody na poparcie hipotezy, że rozmiar piersi wpływa na bolesność układu mięśniowo-szkieletowego.

Wnioski. Ponieważ dostępna literatura na ten temat jest skromna, badania nad wpływem rozmiaru biustu na ból układu mięśniowo-szkieletowego powinny być kontynuowane na większą skalę. Na podstawie przeprowadzonej analizy stwierdzamy, że istnieją znaczne dowody na poparcie hipotezy, że rozmiar piersi wpływa na bolesność układu mięśniowo-szkieletowego.
\end{abstract}

\section{Słowa kluczowe}

rozmiar piersi, ból 